\title{
Obtaining of Grafted Planting Material at Some Romanian Tomatoes
}

\author{
Mădălina DOLTU*, Dorin SORA, Veronica TĂNASĂ \\ Department of Horticultural Cultures in Protected Spaces, Research and Development Institute for \\ Processing and Marketing of Horticultural Products - Horting, Bucharest, Romania \\ *)Corresponding author, e-mail: doltu_mada@yahoo.com
}

BulletinUASVM Horticulture 73(2) / 2016

Print ISSN 1843-5254, Electronic ISSN 1843-5394

DOI:10.15835/buasvmcn-hort:12266

\begin{abstract}
The tomatoes have highest share in Romanian crops from protected spaces (greenhouses, solariums). The grafting is an agronomical technique that induces or improves some qualities of the tomato cultivars (resistance to soil diseases and pests, resistance to abiotic factors, quantity and quality of fruit production). The research was aimed the establishing of the technological stages for producing of scion and rootstock seedlings from $L$. esculentum species, to obtain compatible phenotype when is grafted. The observations of this research were conducted on Department of Horticultural Cultures in Protected Spaces from Horting Institute Bucharest. The experience was carry out on a cultivar collection consisting from L. esculentum plants: Romanian scions ('Siriana'$F_{1}$ hybrid and 'Buzău 1600'- variety), creations from the germplasm bank of Research and Development Station for Vegetable Growing Buzău (VDRS Buzău) and Japanese rootstock ('Groundforce'-F $F_{1}$ hybrid) from Sakata seed. The plant diameters were correlated for splice grafting, cutting at 45 degrees. The grafting was performed successfully. The technological steps have achieved phenotypic compatibility of the plants when was the splice grafting. The technology for producing of grafted planting material at some Romanian tomatoes ('Siriana' and 'Buzău' 1600) was established for the crops in protected spaces in south area of Romania.
\end{abstract}

Keywords: grafted seedlings, Lycopersicon esculentum, Romania

\section{Introduction}

The tomatoes have highest share in Romanian crops from protected spaces (greenhouses, solariums). Leonardi and Romano, 2004 said that some cultivars are not able to adapt to protected cultivation, withstand soil born disease pressure and extreme changes in temperature and moisture. The grafting is an agronomical technique that induces or improves some qualities of the tomato cultivars (resistance to soil diseases and pests, resistance to abiotic factors, quantity and quality of fruit production).

Grafted seedlings are being progressively adopted by vegetable industry as propagules of choice for crop establishment (Leonardi and Romano, 2004). In Romania, the use of grafting techniques started after 1973 (Tomescu, 2005) and it has been developed because soil borne pathogens are a serious problem, that can be avoided by using resistant rootstocks (Doltu et al., 2015). Doltu et al., 2013 say that the grafting can be performed successfully if the plants (scion and rootstock) have similar diametres.

\section{Aims and objectives}

The research was aimed the establishing of the technological stages for producing of grafted planting material at some Romanian tomatoes: sowing of scions and rootstocks from L. esculentum specie, grafting, callusing to obtain compatible phenotype when is grafted and planting in protected spaces in south area of Romania.

\section{Materials and methods}

The observations of this research were conducted on Department of Horticultural 
Tab. 1 Technological dates for obtaining of Romanian grafted tomato seedlings

\begin{tabular}{|c|c|c|c|c|c|c|c|}
\hline$\frac{\text { Scion }}{\text { Rootstock }}$ & $\begin{array}{l}\text { Sowing } \\
\text { data }\end{array}$ & $\overrightarrow{\text { no. of days }}$ & $\begin{array}{c}\text { Emergence } \\
\text { data }\end{array}$ & $\overrightarrow{\text { no. of days }}$ & $\begin{array}{l}\text { Grafting } \\
\text { data }\end{array}$ & $\overrightarrow{\text { no. of days }}$ & $\begin{array}{l}\text { Callusing } \\
\text { data }\end{array}$ \\
\hline 'Siriana' & 19.02 . & 7 & 26.02 . & $21 \mathrm{a}$ & 18.03. & 7 & 25.03 . \\
\hline 'Buzăı 1600 ' & $\begin{array}{l}19.02 . \\
26.02 \text {. }\end{array}$ & $\begin{array}{l}7 \\
6\end{array}$ & $\begin{array}{r}26.02 . \\
3.03 .\end{array}$ & $\begin{array}{r}24 \mathrm{~b} \\
15,18\end{array}$ & $\begin{array}{r}21.03 \\
18-21.03\end{array}$ & $\begin{array}{l}7 \\
7\end{array}$ & $\begin{array}{r}28.03 \\
25-28.03\end{array}$ \\
\hline
\end{tabular}

Cultures in Protected Spaces from Horting Institute Bucharest.

The experience was carry out on a cultivar collection consisting from $L$. esculentum plants: Romanian scions ('Siriana'-F ${ }_{1}$ hybrid, 1000 seeds and 'Buzău 1600'-variety, 1000 seeds), creations from the germplasm bank of Research and Development Station for Vegetable Growing Buzău (VDRS Buzău) and Japanese rootstock ('Groundforce'-F ${ }_{1}$ hybrid, 2000 seeds) from Sakata Seed.

The technology for obtaining of ungrafted seedlings (scions and rootstock) is according to the ecological requirements of the species. The agronomical technique was splice grafting.

The statistical analysis was carried out by Duncan test.

\section{Results and Discussion.}

Obtaining of grafted tomato seedlings implies following steps: sowing of scion and rootstock, preparing for grafting, grafting, forming of callus, transferring of seedlings from the tunnel for callus forming in the growing space. After sowing, the plants are cultivated in classic conditions for tomatoe seedlings.

The technological dates for obtaining of Romanian grafted tomato seedlings there are in table (Tab. 1).

The plants had optimal diameters $(2-2,5 \mathrm{~mm})$ and 2-4 leaves at grafting.

Bogoescu et al., 2008 say that the optimum diameter is $1,5 \mathrm{~mm}$. The grafting was performed successfully (95\% grafted plants/scion cultivar). Duncan test shows as between 'Siriana' and 'Buzău 1600 ' are not significant diference, the grafting was to 21 days ('Siriana') and 24 days ('Buzău $1600^{\prime}$ ) from emergence of scions.

Doltu et al., 2013 say that the grafting of some Japanese hybrids was achieved after 16-18 days and 19-20 days from scion emergence and 13-14 days from the rootstock emergence.

\section{Conclusion}

The technological steps have achieved phenotypic compatibility of the plants when was the splice grafting, the plants (scion and rootstock) had optimal diameters. Between 'Siriana' and 'Buzău 1600' are not significant diference corcerning the grafting.

The technology for producing of Romanian grafted tomato seedlings ('Siriana' and 'Buzău' 1600) was established for the crops in protected spaces in south area of Romania.

\section{REFERENCES}

1. Bogoescu M, Doltu M, Sora D, Iordache B (2008). Results on establishing the technology for obtaining the tomatoes grafted seedlings designed for greenhouses. Bulletin UASVM Horticulture Cluj-Napoca 65(1):147-152.

2. Doltu M, Bogoescu M, Sora D (2013). The influence of seed position on the emergence some rootstocks by Lagenaria siceraria. Bulletin UASVM Horticulture Cluj-Napoca 70(1):239-240.

3. Doltu M, Bogoescu M, Sora D (2013). Technological aspects concerning grafting of some Japanese tomatoes. Journal of Horticulture, Foresty and Biotechnology Timișoara 17(1) :62-65.

4. Doltu M, Bogoescu M, Sora D (2015). Results Concerning the Fusion Capacity of Some Cucurbits Grafted by Different Techniques. Bulletin UASVM Horticulture ClujNapoca 72(1):215-216.

5. Leonardi C, Romano D (2004). Recent issues on vegetable grafting. Acta Horticulture 631:163-174.

6. Tomescu A, Alexandri A (2005). Technology for combating phytopathogenic fungi that cause vascular wilts at solanaceous and cucurbits vegetable species. AGRAL Project 3396/2003. 